\title{
FLOUR MILL WORKERS OCCUPATIONAL NOISE EXPOSURE IN CHANDRAPUR CITY, CENTRAL INDIA
}

\author{
Namrata R. Nimgade and R. K. Kamble*
}

Centre for Higher Learning and Research in Environmental Science,

Sardar Patel College, Ganj Ward, Chandrapur 442 402, India

*Corresponding author: rahulkk41279@yahoo.com

\begin{abstract}
Assessment of occupational noise exposure of flour mill workers in Chandrapur city of central India was carried out during November 2015-January 2016. Total 62 flour mills were selected for this study comprising one, two and three grinding machines operating in the shop floor. The sound level meter was used to measure sound level at $50 \mathrm{~cm}$ and 3 meters from grinding machines at receiver's position during operation. Noise monitoring was also recorded when one, two and three machines were operating individually and simultaneously. The results showed that noise levels when one grinding machine in operation in close proximity $(50 \mathrm{~cm})$ was in the range of $80-97 \mathrm{~dB}(\mathrm{~A})$. Comparison of these observations with that of 3 meters distance; it was observed that noise levels got reduced and in the range of 70-77 $\mathrm{dB}(\mathrm{A})$. In the case of two machines in operation, it was in the range of $95-118 \mathrm{~dB}(\mathrm{~A})$ at $50 \mathrm{~cm}$ distance and reduced to $75-95 \mathrm{~dB}(\mathrm{~A})$ at 3 meters distance. This reduction in noise level was due to the propagation of noise in the ambient environment. Furthermore, daily noise exposure points, exposure points job per task and exposure points per hour were computed by using noise exposure calculator developed by Health and Safety Executive (HSE), United Kingdom. The computation from this calculator revealed that these attributes were directly depended upon noise levels in flour mills and duration of noise exposure. A positive linear Pearson's correlation $(p<0.01)$ was observed between noise level and exposure points per hour. Of the 65 flour mill workers surveyed, $70.76 \%$ reported a hearing problem, $23.07 \%$ headache at work and out of which $7.69 \%$ workers headache remains after completion of work also. Remedial measures to control noise exposure to flour mill workers such as ear plugs, ear muff, semi-insert are recommended.

Keywords: Chandrapur, Flour mill, Grinding machine, Noise exposure, Occupational noise
\end{abstract}

DOI: http://dx.doi.org/10.3126/ije.v7i1.21290

Copyright $\odot 2018 \mathrm{IJE}$

This work is licensed under a CC BY-NC which permits use, distribution and reproduction in any medium provided the original work is properly cited and is not for commercial purposes 


\section{Introduction}

Technological revolution had led to the development of a number of environmental pollutants of which noise is one of the physical types of pollutant. Industrial processes generate noise of sufficient sound levels to cause deafness, temporary hearing loss and other health disorders (Chhatwal et al., 1999). The extent of damage to human's health due to occupational noise depends primarily on the intensity of noise and duration of exposure. Noise remains a common environmental pollutant in industrial workplaces and has been a constant issue since the industrial revolution. Noise-induced hearing loss (NIHL) is an irreversible sensory neural hearing loss associated with excessive noise exposure. Noise in excess of $85 \mathrm{~dB}(\mathrm{~A})$ in a work environment of eight hours daily works regime predisposes workers to NIHL (Rabinowitz, 2005).

About 30 million workers in the USA are exposed to dangerous noise level (Dobie, 1995; Shirali and Zare, 2012) this leads to hearing loss which resulted into hundreds of million dollars loss per year (NIOSH, 1998). Statistics of the WHO evaluates 4 million dollars as daily damage (Motalebi and Hanani, 2003). In Germany, 12-15\% of workers (4-5 million) are exposed to noise level above WHO (2001) defined hazardous noise levels. In developing countries, average noise levels are above the recommended standards (Boateng \& Amedofu, 2004; WHO, 2001; Mithanga, 2013). In Egypt, $70 \%$ of workers were exposed to hazardous noise levels (Ali, 2011); whereas, in Kenya, it was 75.8\% workers (Mithango, 2013).

Noise annoys, distracts, disturbs, and when exposure to it is sufficient, noise can cause physiological effects leading to deafness. Annoyance results from interference with sleep and with speech. Noise makes disturbance and loss of privacy. Distractions accompany noise in the workplace with a consequent reduction in production, efficiency, accuracy, and safety. Prolonged exposure to intense noise causes permanent hearing loss (Chhatwal et al., 1999). Industrial machinery and processes are noise generating media in which their sources include: rotors, stators, fans, vibrating panels, turbulent fluid flow, impact processes, electrical machines, internal combustion engines (Gerges et al., 2001).

Workers are exposed to occupational noise. However, the exposure varies from a developing country to another with respect to occupation, exposure duration, activities carried out etc. Owing to these conditions and socio-economic background of the study area, this study was proposed to carry out with an objective to assess the occupational noise exposure of flour mill workers in Chandrapur city, India. After carrying out online and published literature review for noise levels in flour mill workers in the Chandrapur city, it was found that no such study was carried out previously. Hence, a gap was identified. To fill this knowledge gap by generating a new one in this subject domain this study was proposed to carry out. The main objective of the study was to ascertain the occupational noise exposure of flour mill workers of the Chandrapur city. Furthermore, computation of daily noise exposure, exposure points job per task and exposure points per hour to the individual worker. 


\section{Study area}

Chandrapur formerly Chanda $\left(19.57^{\circ} \mathrm{N}\right.$ latitude and $79.18^{\circ} \mathrm{E}$ longitude) is a city and municipal corporation in Chandrapur District of Maharashtra state of India (Figure 1). The city is located at the confluence of Irai and Zarpat river. The city has higher elevation at north side whereas lower elevation at the south side. The city is situated at an altitude of $189.90 \mathrm{~m}$ above sea level and has an area of $70.02 \mathrm{sq} \mathrm{km}$. The north-south length of the city is about $10.6 \mathrm{~km}$, while the east-west is about $7.6 \mathrm{~km}$. According to 2011 census, the city had a population of 320,379 (Census of India, 2011). In a 2011 state cabinet decision, Chandrapur Municipal Corporation was elevated to D grade Municipal Corporation. The city has 66 wards and divided into 3 zones. The socio-culture environment of the city is still a traditional one. Inhabitants of the city prefer to get different types of flour prepared from flour mill rather than purchasing of packed flour from the market. In Chandrapur city, about 350 flour mills are operating with traditional old machines.

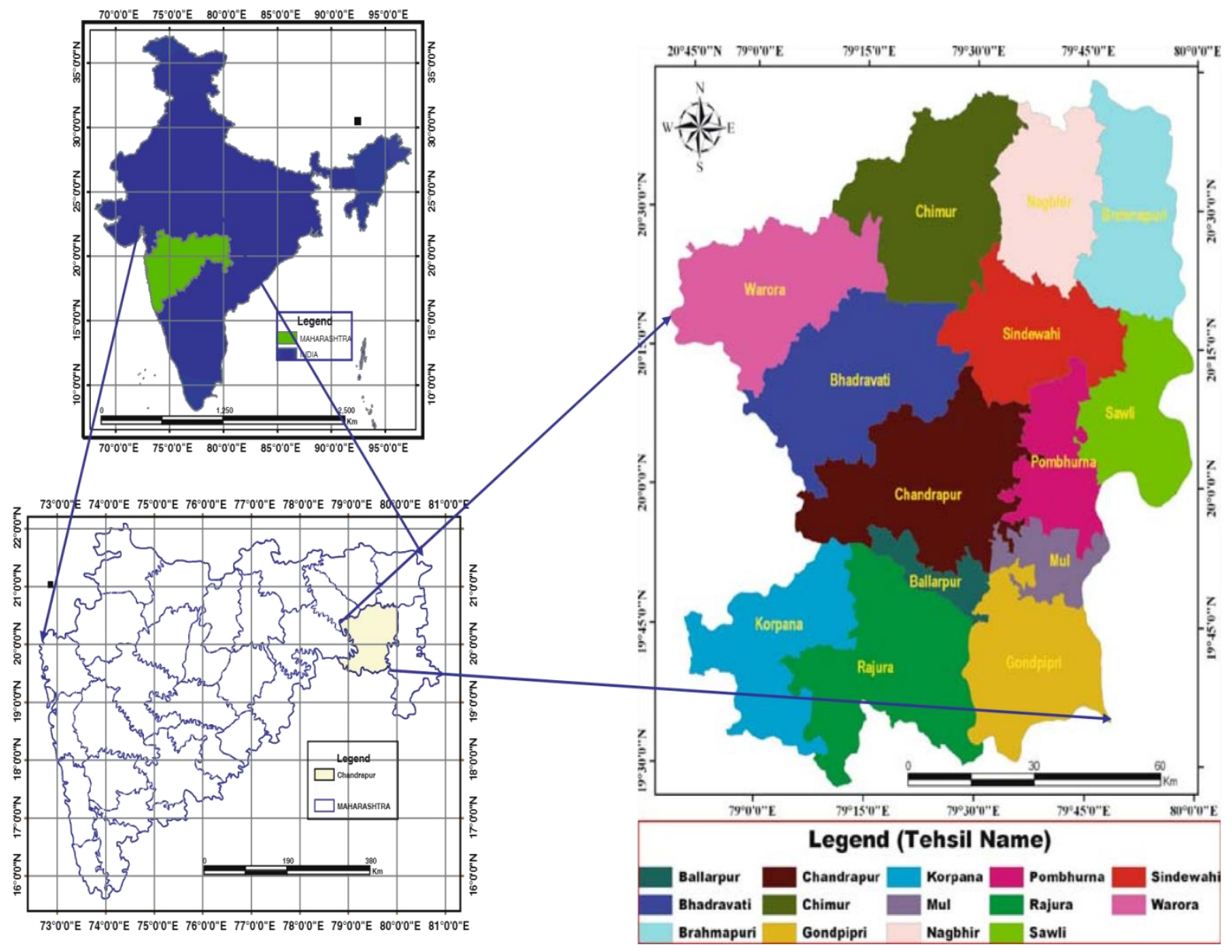

Figure 1. Chandrapur district map (Satapathy, 2009) 


\section{Methodology}

\section{Sampling design}

Total 62 flour mills (20\% of the total flour mill population) were selected for this study. Stratified random sampling methodology was adopted to identify flour mills. Furthermore, while sampling stress was laid upon to cover maximum study area. These flour mills had one, two and in few cases three grinding machines in the shop floor. The preparation of wheat flour was the basic activity in these flour mills in addition to this, spices grinding, which was carried out through a separate grinding machine. The flour mills are typically small employing one or two workers in an area of approximately $500 \mathrm{sq}$ feet. In this small area, traditional flour mill grinding machines were installed. In some sampling locations one, two or three grinding machines were operated in this compact area. The front portion of the flour mill was open; whereas, from remaining all three sides walls were constructed with a small opening for a window in some flour mills. The light intensity was very poor. Comparative characteristics of the workplace environment and surrounding ambient environment in flour mills from the study area are depicted in Table 1.

Table 1. Characteristic of the workplace environment

\begin{tabular}{lll}
\hline Parameters & $\begin{array}{l}\text { Work environment; Range, } \\
\text { (Average) }\end{array}$ & $\begin{array}{l}\text { Ambient } \\
\text { environment } \\
\text { (Average) }\end{array}$ \\
\hline Noise & $\begin{array}{l}79.5-92.0 \mathrm{~dB}(\mathrm{~A}), \\
(85.02 \mathrm{~dB}(\mathrm{~A}))\end{array}$ & $72.5 \mathrm{~dB}(\mathrm{~A})$ \\
& $46-60 \%,(52.00 \%)$ & $63 \%$ \\
Humidity & $30-40{ }^{\circ} \mathrm{C},\left(36^{\circ} \mathrm{C}\right)$ & $31^{\circ} \mathrm{C}$ \\
Temperature & $14.0-19.5 \mathrm{Lux},(16.15 \mathrm{Lux})$ & $125150 \mathrm{Lux}$ \\
Light intensity &
\end{tabular}

In these flour mills, major operations include wheat and spices grinding with daily working for about 6-8 hours a day with maximum stress during evening and night time. During the operation of the machine in addition to dust, the noise was also generated from electric motors, vibration of machines, etc.

\section{Noise level monitoring}

The Sound Level Meter (Center 325 Mini Sound Level Meter, IEC 651 type II, Taiwan) was used to measure sound levels in different flour mills from the study area. The meter was calibrated with an acoustic calibrator before measurements were recorded. Sound levels monitoring was carried out from November 2015 to January 2016. Noise levels were measured at two different distances of $50 \mathrm{~cm}$ (where flour mill operator stands at the time of grinding $)$ and 3 meters $(\mathrm{m})$ from the source at receivers position (1.2 meters from the ground surface). In addition to noise levels in flour mills, sound pressure level (SPL) measurements were also carried out with respect to a) background noise, when all machines were switched off, b) noise produced by each machine, when switched on individually (machines noise) and c) noise produced by all machines when in operation (total noise). 


\section{Noise exposure calculation}

Noise exposure calculator developed by Health and Safety Executive (HSE), UK was used to calculate noise exposure to flour mill workers. The exposure calculator calculates exposure points by job per task along with exposure points per hour by considering noise level and exposure duration in hours. These exposure points can be used to prioritize noise control. The highest exposure points make the greatest contributions to daily noise exposure. Thus, controlling these noise exposures will have the greatest effect on daily noise exposure.

\section{Data analysis}

The data on noise level and exposure points per hour and machine operation distance and average noise level were statistically analyzed by Pearson's correlation coefficient (r) using SPSS software 16.0 to understand the strength of the relation between these two variables.

\section{Results and discussion}

The results for noise level from one, two and three grinding machines at $50 \mathrm{~cm}$ and 3 meters is presented in Tables 2-7. From the Table 2 it was observed that at 24 flour mills with one machine was in operation noise level at $50 \mathrm{~cm}$ from machine was $97 \mathrm{~dB}(\mathrm{~A})$; whereas, at 26 mills it was $95 \mathrm{~dB}(\mathrm{~A})$ and 80 $\mathrm{dB}(\mathrm{A})$ at 10 mills and $87 \mathrm{~dB}(\mathrm{~A})$ at two mills. Exposure points job per task was found to be $1189,750,119$ and 24; whereas, exposure points per hour was 198, 125, 20 and 4 for 24, 26, 2 and 10 flour mills respectively. From the results, it was observed that at $50 \mathrm{~cm}$ distance from the flour mill noise level was in the range of 80 $\mathrm{dB}(\mathrm{A})-97 \mathrm{~dB}(\mathrm{~A})$. Average noise level was $89.75 \mathrm{~dB}(\mathrm{~A})$. The minimum noise level of $80 \mathrm{~dB}(\mathrm{~A})$ is still higher for an individual according to the Occupational Safety and Health Administration (OSHA) standards (Table 9). On comparison of noise level and exposure points, a strong correlation was observed between noise level and exposure points per hour. As the noise level increases, exposure points also increases. Table 3 presents noise levels in flour mills when one grinding machine was in operation at a distance of 3 meters from it. Noise level recorded was $77 \mathrm{~dB}(\mathrm{~A}), 75 \mathrm{~dB}(\mathrm{~A})$ and $70 \mathrm{~dB}(\mathrm{~A})$ at 20, 22 and 20 flour mills respectively. On comparison of noise levels at $50 \mathrm{~cm}$ with 3 meters in these flour mills, it was observed that as distance increases from the source noise levels got reduce and there was a reduction in exposure points per hour. 
Table 2. Noise level and exposure points when one grinding machine in operation $(50 \mathrm{~cm}$ apart from grinding machine)

\begin{tabular}{lllll}
\hline $\begin{array}{l}\text { Number of } \\
\text { flour mills }\end{array}$ & $\begin{array}{l}\text { Noise level } \\
\text { dB(A) }\end{array}$ & $\begin{array}{l}\text { Daily noise } \\
\text { exposure }\left(L_{E P, d}\right)\end{array}$ & $\begin{array}{l}\text { Exposure points } \\
\text { job/task }\end{array}$ & $\begin{array}{l}\text { Exposure points } \\
\text { per hour }\end{array}$ \\
\hline 24 & 97 & $96 \mathrm{~dB}(\mathrm{~A})$ & 1189 & 198 \\
26 & 95 & $94 \mathrm{~dB}(\mathrm{~A})$ & 750 & 125 \\
2 & 87 & $86 \mathrm{~dB}(\mathrm{~A})$ & 119 & 20 \\
10 & 80 & $79 \mathrm{~dB}(\mathrm{~A})$ & 24 & 4 \\
\hline
\end{tabular}

Table 3. Noise level and exposure points when one grinding machine in operation (3 $\mathrm{m}$ apart from grinding machine)

\begin{tabular}{llllc}
\hline $\begin{array}{l}\text { Number } \\
\text { of flour mills }\end{array}$ & $\begin{array}{l}\text { Noise level } \\
\text { dB(A) }\end{array}$ & $\begin{array}{l}\text { Daily } \\
\text { exposure (LEP,d) }\end{array}$ & $\begin{array}{l}\text { Exposure points } \\
\text { job/task }\end{array}$ & $\begin{array}{l}\text { Exposure points } \\
\text { per hour }\end{array}$ \\
\hline 20 & 77 & $76 \mathrm{~dB}(\mathrm{~A})$ & 12 & 2 \\
22 & 75 & $74 \mathrm{~dB}(\mathrm{~A})$ & 8 & 1 \\
20 & 70 & $68 \mathrm{~dB}(\mathrm{~A})$ & 2 & 0 \\
\hline
\end{tabular}

Noise levels and exposure points where two grinding machines were operating at a distance of 50 $\mathrm{cm}$ is presented in Table 4. From the table it was observed, the noise level was $118 \mathrm{~dB}(\mathrm{~A}), 105 \mathrm{~dB}(\mathrm{~A})$ and 95 $\mathrm{dB}(\mathrm{A})$ at 22, 24 and 6 flour mills respectively. Exposure points per hour were 24941, 1250 and 125 respectively. On comparison of noise levels range at $50 \mathrm{~cm}$ where the single machine was in operation with two machines (Tables 2 and 4), it was observed that noise levels range was higher [80-97 dB(A) to 95-118 $\mathrm{dB}(\mathrm{A})]$. The average noise level at the single machine in operation was $89.75 \mathrm{~dB}(\mathrm{~A})$ and $106 \mathrm{~dB}(\mathrm{~A})$ where two machines were operating. An increase of about $16 \mathrm{~dB}(\mathrm{~A})$ was observed in similar flour mills when two machines were operated simultaneously. From the noise levels and exposure points per hour, in this case, it can be observed that they were directly proportional to each other. Furthermore, it was observed that distance plays an important role in exposure per hour. The exposure points job per task for carrying out similar activity for the duration of six hours (average job hours) in a day was higher. 
Table 4. Noise level and exposure points when two grinding machines in operation (50 cm apart from grinding machine)

\begin{tabular}{lllll}
\hline $\begin{array}{l}\text { Number } \\
\text { flour mills }\end{array}$ & $\begin{array}{l}\text { Noise level } \\
\text { dB(A) }\end{array}$ & $\begin{array}{l}\text { Daily } \\
\text { exposure (LE,,d })\end{array}$ & $\begin{array}{l}\text { Exposure points } \\
\text { job/task }\end{array}$ & $\begin{array}{l}\text { Exposure points } \\
\text { per hour }\end{array}$ \\
\hline 22 & 118 & $117 \mathrm{~dB}(\mathrm{~A})$ & 149645 & 24941 \\
24 & 105 & $104 \mathrm{~dB}(\mathrm{~A})$ & 7500 & 1250 \\
6 & 95 & $94 \mathrm{~dB}(\mathrm{~A})$ & 750 & 125 \\
\hline
\end{tabular}

Table 5. Noise level and exposure points when two grinding machines in operation ( $3 \mathrm{~m}$ apart from grinding machine)

\begin{tabular}{llllll}
\hline $\begin{array}{l}\text { Number of } \\
\text { flour mills }\end{array}$ & $\begin{array}{l}\text { Noise level } \\
\text { dB(A) }\end{array}$ & $\begin{array}{l}\text { Daily noise } \\
\text { exposure }\left(L_{E P, d}\right)\end{array}$ & $\begin{array}{l}\text { Exposure points } \\
\text { job/task }\end{array}$ & $\begin{array}{l}\text { Exposure } \\
\text { per hour }\end{array}$ & points \\
\hline 22 & 95 & $94 \mathrm{~dB}(\mathrm{~A})$ & 750 & 125 \\
10 & 90 & $89 \mathrm{~dB}(\mathrm{~A})$ & 237 & 40 \\
9 & 80 & $79 \mathrm{~dB}(\mathrm{~A})$ & 24 & 4 \\
11 & 75 & $74 \mathrm{~dB}(\mathrm{~A})$ & 8 & 1 \\
\hline
\end{tabular}

Noise levels at a distance of 3 meters when two machines were operating are presented in Table 5. From the table, it was observed that the noise level was 95, 90, 80 and $75 \mathrm{~dB}(\mathrm{~A})$ at 22, 10, 9 and 11 flour mills respectively. On comparison of noise levels with a similar situation at $50 \mathrm{~cm}$ distance (Table 4), it was observed that a reduction in noise level. A reduction of $21 \mathrm{~dB}(\mathrm{~A})$ in average noise level was observed in this condition. Similarly, a reduction in exposure points per hour and exposure points job per task on comparison with $50 \mathrm{~cm}$ distance was observed. From the results, it can be concluded that, as subjects, the operator moves away from the noise source, noise level decreases, furthermore, decrease in exposure points per hour and exposure points job per task was also observed.

Table 6 present details pertaining to noise levels, exposure points per hour and job per task at a distance of $50 \mathrm{~cm}$ where three machines were operating simultaneously. This type of situation was observed in five sampling locations only. In these sampling locations, the noise level was in the range from $123 \mathrm{~dB}(\mathrm{~A})$ to $130 \mathrm{~dB}(\mathrm{~A})$ and average noise level was $126.5 \mathrm{~dB}(\mathrm{~A})$. A noise exposure point per hour was in the range of 395285 to 78870 and exposure points job per task was 2371708 to 473218 . From the results it can be observed, simultaneous operating of three machines had resulted into increase in average noise level as compared with one and two machines operating and furthermore increase in exposure points per hour and job per task. 
Table 6. Noise level and exposure points when three grinding machines in operation (50 cm apart from grinding machine)

\begin{tabular}{lllll}
\hline $\begin{array}{l}\text { Number } \\
\text { flour mills }\end{array}$ & $\begin{array}{l}\text { of } \\
\text { dB(A) }\end{array}$ & $\begin{array}{l}\text { Daily } \\
\text { exposure(LEP,d) }\end{array}$ & $\begin{array}{l}\text { Exposure points } \\
\text { job/task }\end{array}$ & $\begin{array}{l}\text { Exposure points } \\
\text { per hour }\end{array}$ \\
\hline 3 & 130 & $129 \mathrm{~dB}(\mathrm{~A})$ & 2371708 & 395285 \\
2 & 123 & $122 \mathrm{~dB}(\mathrm{~A})$ & 473218 & 78870 \\
\hline
\end{tabular}

Table 7. Noise level and exposure points when three grinding machines in operation ( $3 \mathrm{~m}$ apart from grinding machine)

\begin{tabular}{llcll}
\hline $\begin{array}{l}\text { Number } \\
\text { of flour mills }\end{array}$ & $\begin{array}{l}\text { Noise } \\
\text { level dB(A) }\end{array}$ & $\begin{array}{l}\text { Daily noise } \\
\text { exposure (LEP,d) }\end{array}$ & $\begin{array}{l}\text { Exposure } \\
\text { job/task }\end{array}$ & $\begin{array}{l}\text { points } \\
\text { Exposure points per } \\
\text { hour }\end{array}$ \\
\hline 3 & 117 & $116 \mathrm{~dB}(\mathrm{~A})$ & 118867 & 19811 \\
2 & 110 & $109 \mathrm{~dB}(\mathrm{~A})$ & 23717 & 3953 \\
\hline
\end{tabular}

Noise levels at a distance of 3 meters when three machines were operating simultaneously are presented in Table 7. From the table it can be observed, the noise level was in the range from $110 \mathrm{~dB}(\mathrm{~A})$ to $117 \mathrm{~dB}(\mathrm{~A})$ and average noise level was $113.5 \mathrm{~dB}(\mathrm{~A})$. Exposure points per hour were in the range was 19811 and 3953; whereas, exposure points job per task was 118867 to 23717 . On comparison of noise levels at the similar situation at $50 \mathrm{~cm}$ distance (Table 6), it was observed that noise level was in the range of $123 \mathrm{~dB}(\mathrm{~A})$ to $130 \mathrm{~dB}(\mathrm{~A})$ with an average of $126.5 \mathrm{~dB}(\mathrm{~A})$. A reduction in noise levels and the average noise level was observed when noise measurement was recorded at 3 meters distance from flour mills. Propagation of noise in the surrounding ambient environment had reduced noise levels at this distance.

Comparison of noise levels and average noise at different flour mill operating conditions is presented in Table 8. From this table, it was observed, in close proximity to the noise source $(50 \mathrm{~cm})$ noise level range and the average noise level was more. At 3 meters distance, noise level and average noise level decreases. It can be concluded that noise propagation in the ambient environment at 3 meters distance resulted in decrease was noise level as compared with $50 \mathrm{~cm}$ distance.

Table 8. Comparison of noise level range and average noise level

\begin{tabular}{llll}
\hline $\begin{array}{l}\text { Flour mill operating } \\
\text { condition }\end{array}$ & $\begin{array}{l}\text { Noise sampling } \\
\text { distance } \\
\text { source }\end{array}$ & $\begin{array}{l}\text { Noise level } \\
\text { range dB(A) }(\mathbf{A})\end{array}$ & $\begin{array}{l}\text { Average noise } \\
\text { level dB(A) }\end{array}$ \\
\hline Single machine & $50 \mathrm{~cm}$ & $80-97$ & 89.75 \\
& $3 \mathrm{~m}$ & $70-77$ & 74.0 \\
Two machines & $50 \mathrm{~cm}$ & $95-118$ & 106.0 \\
& $3 \mathrm{~m}$ & $75-95$ & 85.0 \\
Three machines & $50 \mathrm{~cm}$ & $123-130$ & 126.5 \\
& $3 \mathrm{~m}$ & $110-117$ & 113.5 \\
\hline
\end{tabular}

$\mathrm{m}$ - meters, $\mathrm{cm}$ - centimeters 
Occupational Safety and Health Administration (OSHA), USA limited the maximum exposure time to eight hours per day for a continuous sound pressure level of $90 \mathrm{~dB}(\mathrm{~A})$ (Table 9). According to OSHA regulations, every $5 \mathrm{~dB}(\mathrm{~A})$ increase in noise level cuts the allowable exposure time to half and is known as 5 $\mathrm{dB}(\mathrm{A})$ doubling rate (Olishifski and Standard, 1988). The results of the study revealed at a number of sampling locations at $50 \mathrm{~cm}$ distance noise levels were above OSHA permissible noise exposure limit. This indicates workers may face temporary hearing loss and prolonged exposure to these noise levels can lead to permanent hearing loss and other non-auditory effects also. Of the 65 flour mill workers surveyed during the study, $70.76 \%$ reported a hearing problem, $23.07 \%$ headache at work and out of which $7.69 \%$ workers headache remains after completion of work also.

Table 9. Occupational Safety and Health Administration permissible noise exposures

\begin{tabular}{cc}
\hline Duration/day (hours) & $\begin{array}{l}\text { Sound } \\
\text { (Slow response) }\end{array}$ \\
\hline 8 & 90 \\
6 & 92 \\
4 & 95 \\
3 & 97 \\
2 & 100 \\
1.5 & 102 \\
1.0 & 105 \\
0.5 & 110 \\
0.25 & 115 \\
\hline
\end{tabular}

In order to quantitatively analyzed and confirm the relationship between noise level and exposure points per hour, Pearson's correlation coefficient analysis was applied to the data (Table 10). There was a statistically significant positive correlation between these two variables. The total positive linear correlation was found between three machines at a distance of $50 \mathrm{~cm}$ and 3 meters with exposure points per hour $(p<0.01)$. Machine operation distance of $50 \mathrm{~cm}$ and the average noise level was strongly correlated $(p<0.05)$ (Table 11).

Table 10. Pearson's correlation coefficient between noise level and exposure points per hour

\begin{tabular}{lll}
\hline Grinding machine in operation & $\begin{array}{l}\text { Persons correlation } \\
\text { coefficient }(\mathbf{r})\end{array}$ & Sig. (2-tailed) \\
\hline One machine $(50 \mathrm{~cm})$ & 0.932 & 0.068 \\
One machine $(3$ meters) & 0.971 & 0.154 \\
Two machines $(50 \mathrm{~cm})$ & 0.918 & 0.260 \\
Two machines $(3$ meters $)$ & 0.887 & 0.113 \\
Three machines $(50 \mathrm{~cm})$ & $1.00^{* *}$ & \\
Three machines $(3$ meters) & $1.00^{* *}$ & \\
\hline
\end{tabular}

***Correlation significant at 0.01 level (2-tailed) 
Table 11. Pearson's correlation coefficient between machine operation distance and average noise level

\begin{tabular}{lll}
\hline Grinding machine in operation & $\begin{array}{l}\text { Persons correlation } \\
\text { coefficient }(\mathbf{r})\end{array}$ & Sig. (2-tailed) \\
\hline At $50 \mathrm{~cm}$ distance & $0.998^{*}$ & 0.038 \\
At 3 meters distance & 0.969 & 0.159 \\
\hline
\end{tabular}

*Correlation significant at 0.05 level (2-tailed)

According to Rasheed and Khan (2005) most of the flour mill plant was mechanically operated, so a high noise rate was observed which was in accordance with the results obtained from this study. Elias et al., (2104) reported noise pollution in maize milling from 89-103 dB(A) in DSM and 92-103 dB(A) in Morogoro. Results obtained from the study were comparatively higher where two and three machines in operation at 50 cm distance. Mohammadizadeh et al., (2015) revealed noise pollution in a flour factory had an impact on workers hearing. Pearson's relationship $\mathrm{r}=0.453$ among job reports and the performance decline between all operators by significant stage $p<0.05$. These results are in agreement with the results obtained in the study. A study by Ferrite and Sanata (2005) reported a direct link between age, hearing loss and occupational exposure to noise. Hong and $\mathrm{Kim}$ (2001) stated a relationship between occupational exposure to noise and the hearing loss. In a study carried out by Balachew and Berhane (1999) for noise-induced hearing loss among textile workers the relation between hearing reduction, age, and work experience was established. These results are in accordance with the results obtained from the study. Highest noise levels in a wheat processing factory in Nigeria was $99.4 \mathrm{~dB}(\mathrm{~A})$ (Ibrahim et al., 2016) which was in agreement with the results obtained in the study where two machines were operating at a distance of $50 \mathrm{~cm}$. Boateng and Amedofu (2004) reported noise levels in corn mills to exceed the limiting value of $85 \mathrm{~dB}(\mathrm{~A})$ as recommended by NESREA. Furthermore, it was found $23 \%, 20 \%$ and $7.9 \%$ of workers in corn mills, sawmills, and printing industry had evidence of noise-induced hearing loss which was correlated with noise exposure level and duration of exposure. Prasanna Kumar et al., (2008) stated workers engaged in oil mills were exposed to high noise, which had detrimental effects on their health. A study carried out in a textile factory by Mohammadi et al., (2009) reported hearing loss, physiological and physiological effects of noise pollution. Noise levels in a cement industry were higher than $\mathrm{WHO}$ acceptable limit. Hearing loss eventually developed to noise level above $85 \mathrm{~dB}(\mathrm{~A})$ which workers were aware of (Mndeme and Mkoma, 2012). Flour mill workers were not aware of noise-induced hearing loss; however, they had reported the hearing problem. Noise levels and exposure periods in many of the feed mills were above the code specification which indicates a threat to employees health (Mijinyawa et al., 2012). Acoustic over-exposure and human health in flour mill revealed a significant effect of high noise level on the health status of the members of staff (Obiefuna et al., 2018) which was in agreement with the results obtained 
from the study. Workers had reported a hearing problem, headache during and after the work. Gongi et al., (2016) reported a loss of hearing (7\%), headache (36\%), ringing sound in the ears (19\%), irritability (15\%) and sleeplessness (9\%) in workers which was also observed from the results of the study.

\section{Conclusion}

From the results, it can be concluded that noise levels were higher near the source $(50 \mathrm{~cm})$ and as one moves from the noise source (3 meters) noise level got reduced. Similar observations were observed for exposure points per hours and job per task also. It can be concluded that noise exposure was more near the source and got reduced as the distance increases. The workers in flour mills can reduce their exposure to the noise level, by operating one machine at a time and working at a distance from the machine. Furthermore, when it is inevitable to avoid to work from a distance and to work in single machine operating condition at such situation it is advised to use personal protective equipment such as ear plugs, ear muffs or mouldable earplugs. Use of WHO class-4 hearing protector is recommended in flour mill area. Wall acoustic of the flour mill area should be made to absorb sound emitted from the machines. Noise level should not exceed the occupational health standard limit as stipulated by OSHA, USA. Personal isolation from such noisy environment for a day or two in each week can reduce to some extent the adverse effects from noise exposure. Regular medical check-up to ensure healthy auditory condition will avert hearing related problems in future in addition to this, regular maintenance of grinding machines and use of modern machines in place of old one will reduce noise generation from these machines. Use of acoustic material or use of biological noise barriers in an around flour mill will further reduce propagation of noise in surrounding environment.

\section{References}

Ali, S.A., 2011. Industrial noise levels and annoyance in Egypt. Applied Acoustics, 72(4): 221-225.

Balachew, A., Berhane, Y., 1999. Noise-induced hearing loss among textile workers. Ethiopian Journal of Health Development, 13:69-75.

Boateng, C.A., Amedofu, G.K., 2004. Industrial noise pollution and its effect on the hearing capabilities of workers: A study from sawmills, printing presses, and com mills. African Journal of Health Sciences, 11(1-2): 55-60.

Census of India, 2011. www.census 2011.co.in/census/city/355-Chandrapur.html. Accessed on 28 February, 2017.

Chhatwal, G.R., Mehra, M.C., Katyal, M.C., Satake, M., Katyal, M., Nagahino, T. (Eds.) 1999. In: Environmental noise pollution and its control. Anmol Publications Pvt. Ltd. New Delhi. India, 1 p.

Dobie, R., 1995. Economic compensation for hearing loss. International Medicine and Environmental Health, 10(3): 663-668. 
Elias, E., Majaja, B.A., Ibrahim, S., Kizima, E.G.R., 2014. Noise pollution in maize milling SMEs. Tanzania Journal of Engineering and Technology, 35 (1): 34-45.

Ferrite, S., Sanata, V., 2005. Joint effects of smoking, noise exposure and age on hearing loss. Occupational Medicine, 55(1): 48-53.

Gerges, S.N.Y., Sehrndt, G., Parthey, W., 2001. Strategies for noise surveys, In: B. Goelzer, C.H. Hansen, G.A. Sehrndt (Eds.) Occupational Exposure to Noise: Evaluation, Prevention and Control (Germany: Federal Institute for Occupational Safety and Health, on behalf of the World Health Organization), 141-182 p.

Gongi, S.P., Kaluli, J.W., Kanali, C.L., 2016. Industrial noise pollution and its health effects on workers in Nairobi city. International Journal of Engineering Research \& Technology, 5 (9): $426-435$.

Health and Safety Executive. Standard Noise Calculator (Daily Noise Exposure), United Kingdom. http://www.hse.gov.uk/noise/calculator.htm. Accessed on 23 March 2016.

Hong, O.S., Kim, M.J., 2001. Factors associated with hearing loss among workers of the airline industry in Korea. ORL-HeadNeck Nursing, 19(1):7-13.

Ibrahim, I., Ajao, K.R., Aremu, S.A., 2016. Industrial noise level in a wheat processing factory in Ilorin, Nigeria. International Journal of Applied Mechanics and Engineering, 21 (2): 511-523.

Mijinyawa, Y., Ogbue, C.R., Arosoye, O.E., 2012. Assessment of noise levels generated in some feed mills in Ibadan, Nigeria. Research Journal in Engineering and Applied Sciences, 1.1 (3):156-159.

Mithanga, J., Gatebe, E., Gichuhi, M., 2013. Evaluation of noise levels in manufacturing sectors in Thika district, Kenya. Journal of Agriculture, Science and Technology, 15 (1): 137-146.

Mndeme, F.G., Mkoma, S.L., 2012. Assessment of work zone noise levels at a cement factory in Tanga, Tanzania. Ethiopian Journal of Environmental Studies and Management, 5 (3): 225-231.

Mohammadi, M.R., Nassiri, P., Shalkouhi, P.J., 2009. Risk assessment of workers exposed to noise pollution in a textile plant. International Journal of Environmental Science and Technology, 6 (4): 591-596.

Mohammadizadeh, M., Ahmadi, S.H., Sekhavati, E., Ahani-Jegar, K., 2015. Noise pollution effect in flour factory on workers' hearing in Lamerd city. Journal of Medicine and Life, 8, Special Issue 3: 208211

Motalebi, K.M., Hanani, M., 2002. The effect of training of work correct procedure on the rate workers exposure with noise at Macaroni manufacture in Kashan. The first national symposium of noise, health, and development. Mashhad Medical University. 2-3 March 2003.

National Institute for Occupational Safety and Health (NIOSH). Criteria for a Recommended Standard Occupational Noise Exposure Revised Criteria. 1998, DHHS (NIOSH) Publication, 98-126. 
Obiefuna, J.N., Kuba, J.B., Obieguna, C.J., 2018. Acoustic over-exposure versus human health: A case study of Dangote flour mill, Calabar, Cross River state. Environmental Pollution and Protection, 3 (1): 112.

Occupational Safety and Health Administration (OSHA). https://www.osha.gov/pls/oshaweb/owadisp.show_document?p_table=STANDARDS\&p_id=973 5. Accessed on 2 April 2016.

Olishifski, J.B., Standard, J.J., 1988. Industrial noise. In: Plong, B. A. (Ed.) Fundamentals of industrial hygiene, National Safety Council, 163-203 p.

Prasanna Kumar, G.V., Dewangan K.N., Sarkar, A., 2008. Noise exposure in oil mills. Indian Journal of Occupational and Environmental Medicine, 12 (1): 23-28.

Rabinowitz, P., Rees, T., 2005. Occupational hearing loss. In: Rosenstock, Cullen, M., Bodkin, C., Relic, C., (Eds.) Textbook of Occupational and Environmental Medicine ( $2^{\text {nd }}$ Ed.) Philadelphia, USA: Elsevier Saunders, $426-436 \mathrm{p}$.

Rasheed, S., Khan, Z., 2005. Occupational health and safety issues in Sihala flour and general mills (Pvt.) limited in I-9 Industrial zone, Islamabad: a case study. Pakistan Engineering Congress, $71^{\text {st }}$ Annual session proceedings, $577-598 \mathrm{p}$.

Satapathy, D.R., Salve, P.R., Katpatal, Y.B. 2009. Spatial distribution of metals in ground/surface waters in the Chandrapur district (Central India) and their plausible sources. Environmental Geology, 56 (7), 1323-1352.

Shirali, G.A., Zare, S.M.J., 2012. A framework for determining effectiveness of noise control method using fuzzy approach. Jundishapur Journal of Health Sciences, 4(4): 59-64.

WHO, 2001. Occupational and community noise. Geneva, World Health Organization (Fact Sheet No. 258). 